SCJR 16, no. 1 (2021): 1-3

\title{
James Bernauer, S.J. Jesuit Kaddish: Jesuits, Jews, and Holocaust Remembrance
}

(Notre Dame, IN: Notre Dame University Press, 2020), hardcover, xxx + 187 pp.

\author{
MARTINA CUCCHIARA \\ cucchiaram@bluffton.edu \\ Bluffton University, Bluffton, OH 45817
}

In this excellent volume, James Bernauer, S.J., the Kraft Family Professor of Philosophy emeritus and former director of the Center for Christian-Jewish Learning at Boston College, offers "a meditation on the drama of the Holocaust and the Jesuits" (xvii). Grounding his analysis in the Jesuit spiritual practices of "the examination of conscience and the discernment of spirit," Bernauer focuses on the uncovering of "fragments that are essential for the evolution of a more comprehensive perspective on the Holocaust and the Jesuit order's relation to it" (xvii-xiv). It is Bernauer's abandonment of a grand narrative which makes this book so valuable. This freed the author to analyze this topic from different angles through a variety of lenses, which in turn illuminate fresh approaches to the study of the Catholic Church and the Holocaust.

In the first of five chapters, Bernauer focuses on the papacy, in particular on Pope John Paul II and his crucial role in advocating a new relationship between Jews and Christians. As a witness of Nazi crimes and Jewish suffering in war-torn Poland, the pontiff issued a grave summons to the Catholic Church and to Catholics to take "stock not of everyday failures but rather of epochal depravity" (2). After retracing John Paul II's pilgrimages to Nazi death camps, the Synagogue of Rome, and Yad Vashem in Israel, the author highlights the Catholic Church's statements on the Holocaust, including "We Remember: A Reflection on the Shoah" published in 1998 by the Vatican's Commission for Religious Relations with the Jews. Although Bernauer does not deny the statement's major flaws, he argues for its intrinsic value because in it, the Catholic Church expresses sorrow for its failures, admits the guilt of Catholics, and repudiates racism and antisemitism.

Bernauer, a Jesuit, focuses on the Society of Jesus, which has yet to issue such a statement. He makes clear early on that "one of my goals of this volume is to establish the need and rationale for such an apology" (xxii). He continues making his case in chapter two with an examination of the Jesuits' longstanding hostility toward Jews. Although the Jesuit founder Ignatius of Loyola supported Pope Paul IV's 1555 anti-Jewish edict "Cum nimis absurdum," he welcomed Jewish converts 
into the ranks of his new movement. But within a few short decades the Jesuits yielded to ecclesiastical and political pressures and banned the admission into their ranks of Catholics of Jewish and Muslim descent. The Jesuits' attitude toward Jewish heritage thus shifted from "one of honor to that of shame," and the chapter examines the consequences of this change (26). Bernauer argues that alongside the familiar tropes of Christian antisemitism, Jesuit antisemitism also revealed itself in a "distinctive dialect...that might be described as asemitism" (27). Asemitism purported to disavow violence against Jews but advocated Christians' extreme indifference toward them. It was a desire for Jews' invisibility. Readers no doubt will welcome Bernauer's careful attention to the nuances of Catholic views of Jews. But they also may find that asemitism does not capture fully Jesuits' antisemitism, because far from being indifferent to Jews or rendering them invisible, some Jesuits took an active part in the Catholic Church's creation and magnification of the ubiquitous antisemitic image of the "dangerous Jews" in the modern era.

Bernauer continues this examination of the construction of the Catholic fantasy of the Jew in chapter three. Specifically, he focuses his superb analysis on the intersection of the Catholic Church's moral teachings and antisemitism. Here the author applies the lens of sexuality studies to gain deep and nuanced insights into the "more subtle de-structiveness" of Catholic moral teachings on sexuality (51). Bernauer makes a convincing case that the pathology that "seemed to flourish in modern religious culture's charting of sexuality" became "the source of one of Christianity's own greatest weaknesses in its encounter with Nazism" (53). These weaknesses manifested themselves in a number of ways, such as in the principal Christian struggle of the soul against the body, in which Jews came to represent an excessive and sinful carnality. Catholic teachings on sexuality thus had some overlap with later genocidal attacks on Jews, because long before Christians abandoned Jews in the Third Reich, Catholic teachings on the carnality of Jews already had "reduced them to an animal level, a status that would soon come to be reflected in the forms of Nazi torture" (61). Other Catholic moral teachings abetted Nazism, which included the fostering of obedience and submissiveness and the cultivation of a state of oppressive pessimism and pervasive sinfulness. In this context, Nazism either became an ally of Christians in the pursuit of moral renewal or offered an escape from a suffocating sexual code. Bernauer demonstrates here the profitability and need for innovative, fresh approaches to the study of the Catholic Church under Nazism, and his sophisticated analysis in this chapter is a high point of the book. The author also should be commended for showing a welcome sensitivity to gender and women throughout the volume, which still is rare in works on the Catholic Church under Nazism.

Chapter four shifts to the Jesuit righteous whose autonomous judgment and courageous actions during the Holocaust set them apart from the majority of their brethren and helped them overcome the Church's traditional hostility toward Jews. Bernauer posits "that the righteous have not yet found their place on the landscape of our moral imagination," which perhaps is the case because the righteous bring the Catholic Church's abject failure during the Holocaust into sharp relief (99). He examines the "spiritual insurrection" of Jesuits like Father Pierre Chaillet, who 
have been recognized by Israel as Righteous Among the Nations (78-85, and a helpful appendix provides brief biographies of all the Jesuits honored by the State of Israel). But Bernauer also casts his net wider and examines the righteous actions of Jesuits not on this list, such as Father Friedrich Muckermann and Father Augustin Rösch. The author especially is interested in the spiritual source of these Jesuits' positive attitudes and actions toward Jews and Judaism, which he argues probably was "a special respect for the Jewish scripture that they had studied seriously and prayed over earnestly through the years" (69-70). Bernauer ends his study in chapter five with a discussion of Ignatian spiritual exercises and then proposes "a Jesuit statement of repentance as a spiritual response to the analyses of this volume" (103). The statement represents a fitting conclusion to this superb volume. While the book is most insistently addressed to members of the Society of Jesus, it is far from parochial and achieves a breadth and depth that will speak to a broad audience of scholars. 